\title{
管群を横切る気泡流の流動特性*
}

\author{
岩 城 智香子*1, チョン・カーウィー*2 \\ 文 字 秀 明*3, 松 井 剛 - *4
}

\section{Characteristics of Bubbly Cross-Flow over Tube Bundles}

\author{
Chikako IWAKI*5, Cheong KARHOOI, \\ Hideaki MONJI and Goichi MATSUI \\ ${ }^{* 5}$ Power \& Industrial Systems Research \& Development Center, Toshiba Corporation, \\ Shinsugita-cho, Isogo-ku, Yokohama-shi, Kanagawa, 235-8523 Japan
}

\begin{abstract}
Shell and tube type of heat exchangers are widely used in many applications. Understanding on the cross-flow over tube bundles in a shell is not well established due to the flow complexity and difficulty in measurement, especially in the case of two-phase flow. More detailed and accurate velocity data are needed in order to establish reliable design and optimum performance for tube bundle models. This study was aimed at clarifying the structure of bubbly cross-flow over tube bundles by obtaining detailed velocity data using Particle Image Velocimetry (PIV). Experiments were conducted on two types of model, in-line and staggered tube bundles with pitch-to-diameter ratio of 1.5 , containing 20 rows of five $15 \mathrm{~mm}$ O.D. tubes in each row. The images of liquid flow and bubbles were distinguished by optical filtering and image processing techniques. The velocities of liquid flow and bubbles were measured successfully and characteristics of the bubbly cross-flow were clarified.
\end{abstract}

Key Words: Bubbly Cross-Flow, Tube Bundles, PIV, Flow Structure, Optical Filtering

\section{1. 要}

化学工業, 発電プラント, 食品工業など様々な分野 において重要な役割を果たしている熱交換器の中でも, シェル・チューブ型の熱交換器は最も一般的であり, ケトル式リボイラ, 給水加熱器, 蒸発器, 換気空調器 などに幅広く利用されている. シェル・チューブ型の 熱交換器設計においては，その伝熱流動特性を把握す ることが必要不可欠である. 特に, 管群を横切る流れ の圧力損失，管内外の熱伝達係数を評価することなど が重要となる,これらは, 工学的には種々の経験的な 計算式によって，ある程度評価することが可能である が，いずれもその使用範囲には制限がある.

管群を横切る流れの実験的な研究は, 圧力損失, 熱 伝達に着目した研究がいくつか報告されている[1] [8].

* 原稿受付 2004 年 9 月 24 日.

*1 正員, (株)東芝電力・社会システム技術開発センター ( 3235 - 8523 横浜市新杉田町 8).

*2 筑波大学大学院システム情報工学研究科 $($ 305-8573 つく ば市天王台 1-1-1)

*3 正員, 筑波大学システム情報工学研究科.

*4 正員. 近畿大学生物理工学部 ( $349-6493$ 和歌山県那賀郡 打田町西三谷 930)

E-mail : chikako.iwaki@ toshiba.co.jp
しかしながら，これらの報告は，可視化による流れの 定性的な傾向や圧力損失, 熱伝達係数の実験式に着目 したもので, 詳細な流動構造については明らかにされ ていない. したがって, 熱交換器としての性能評価や 信頼性のある設計手法を確立するためには，より詳細 で正確な流動構造の把握が求められている.

画像処理計測の一つである PIV (Particle Image Velocimetry) はセンサ挿入による流れ場の擋乱がなく, 流れ場の 2 次元平面における計測データが瞬時に得ら れるという利点があるため，管群周りの流れなど，特 に障害物のある流れ場の計測には有効である．管群を 横切る流れ場にPIV を適用した結果については, 液単 相の場合はすでに報告されている[9].

ところで, 熱交換器内の流れは, ケトルリボイラや 蒸発器など相変化を伴うものが多く, 少なくともその 60\%は二相流であるとされている. しかしながら，熱 交換器内の流れが二相流の場合の流動構造はよくわか っておらず，工学的に重要なボイド率や流動様式など の評価には，均質流を仮定したモデルや円管内の流動 様式が使用されているのが現状である. そこで本研究 では，PIV を用いて管群を横切る二相流の流動特性を 明らかにすることを目的とする. 実機の熱交換器のボ 
イド率は広範囲であるが, ここでは PIV による計測が 可能である低ボイド率の流れを対象とした.

\section{2. 試験装置および計測方法}

$2 \cdot 1$ 可視化試験体およひ試験装置試験体の配 列は実機の管群の一部を切り出した形状を模擬してお り，寸法は実機の值を参考にして定めた. 最も代表的 な形状として, 図 1 に示すように正方配列と千鳥配列 の 2 体を製作した、いずれも管径 $d=15 \mathrm{~mm}$ ，ピッチ と管径との比 $p / d=1.5$ で, 1 段 5 本で 20 段の配列とし た. 壁の影響を排除するため, 両端の管は半分壁に

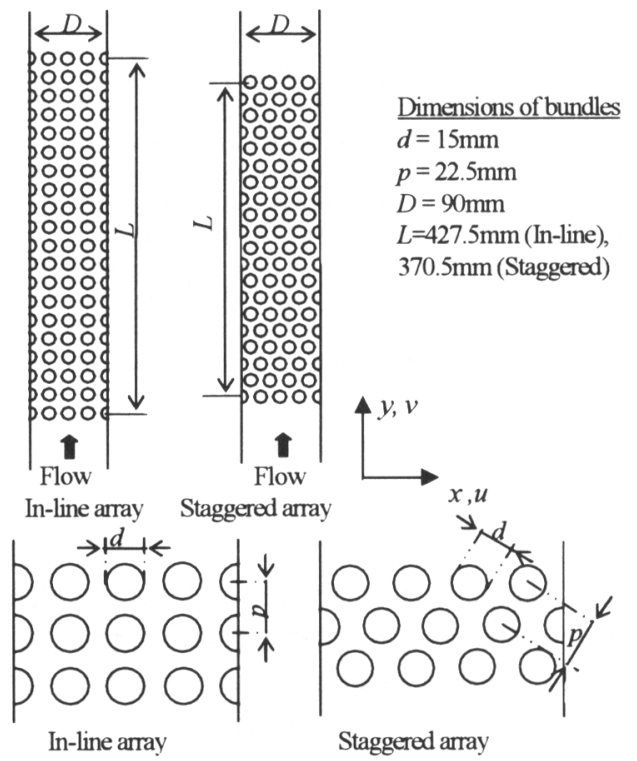

Fig. 1 Test section

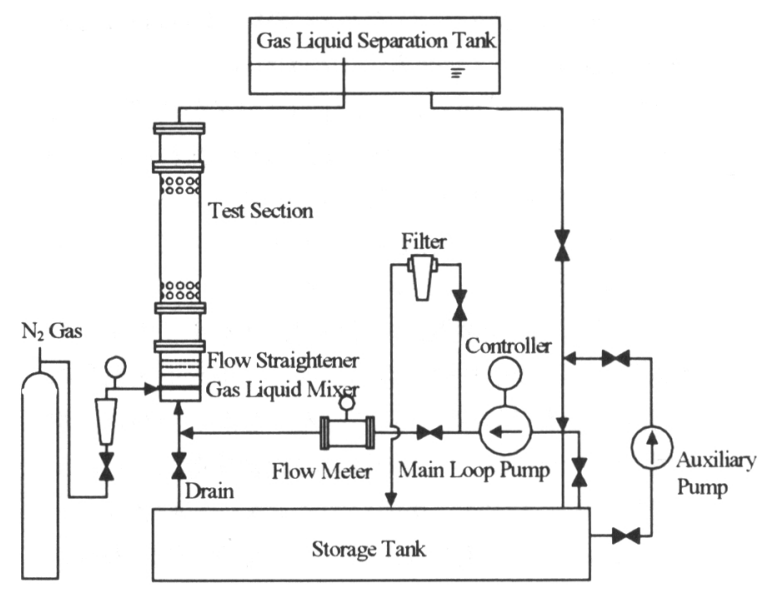

Fig. 2 Schematic diagram of test loop
Table 1 Experimental conditions

\begin{tabular}{l|l}
\hline Liquid flow rate $\left[\mathrm{m}^{3} / \mathrm{h}\right]$ & $0.60-6.48$ \\
Liquid superficial velocity $j_{L}[\mathrm{~m} / \mathrm{s}]$ & $0.037-0.4$ \\
Gas flow rate $[1 / \mathrm{min}]$ & $0.5-2.0$ \\
Gas superficial velocity $j_{G}[\mathrm{~m} / \mathrm{s}]$ & $1.8 \times 10^{-3}-7.4 \times 10^{-3}$ \\
Quality & $3.4 \times 10^{-6}-1.4 \times 10^{-4}$ \\
Pressure & Atmospheric pressure \\
Temperature $\left[{ }^{\circ} \mathrm{C}\right]$ & $25-28$ \\
\hline
\end{tabular}

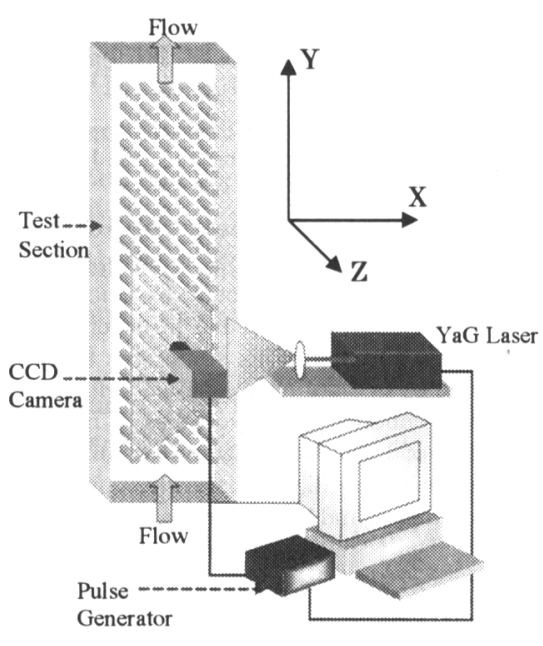

Fig. 3 PIV measurement system

埋め込む構造とした. 流路は $90 \mathrm{~mm} \times 50 \mathrm{~mm}$ の矩形状の チャンネルで, レーザーで内部の流れを可視化するた めにアクリル製材で製作した. また管群にはパイレッ クスガラス棒を用いた。試験体は, 図 2 に示すような ポンプ駆動式の循環ループに取り付けられ, 試験体下 部に取り付けた $10 \mu \mathrm{m}$ 孔の焼結金属から窒素ガスを吹 き込み，試験体に流入寸る流れが気泡流となるように した. 液体と窒素ガスの流量を計測し, 気液の流量を それぞれ変えて実験を行った. 実験条件を表 1 に示寸.

2-2 計測方法 液相と気泡のそれぞれの流速に 対して, PIV を用いて可視化計測を行った. 計測系を 図 3 に示す。レーザー光をシート状にして試験体側部 より照射し，圾験部を流れる流体中のトレーサ粒子か らの散乱光の画像を CCD カメラによって取得する. 試験体の内部の流れは $z$ 方向の分布がなくほぼ二次元 流と見なせるため, $x-y$ 平面の $z$ 座標中心位置にシート レーザーを照射した. レーザーには YaG レーザを用い， これをパルス照射して CCD カメラによる撮影時刻を レーザーシートの発光タイミングと合わせ, 所定の短 い時間間隔で得た 2 枚の画像デー夕を基に, 相互相関 法を用いて速度ベクトルを得た。レーザーおよび 
CCD カメラはそれぞれ計測ステージに設置し, 高さ を調節して試験体の各断面の計測を行った.

管群などのような構造物を含む流路内の流れを可 視化する際には, 構造物と周囲流体との間で屈折率 が異なる場合, 可視化に必要なスリット光が媒体の 境界面において屈折し不均一照明となり，PIVによ る画像解析が不正確となる ${ }^{[10]}$. 本研究ではこの問題 を解決するために，管群をパイレックスガラス棒で 模擬し，作動流体としてパイレックスガラス棒と等 しい屈折率をもつ液体として, 濃度 $56.9 \mathrm{wt} \%$ の $\mathrm{NaI}$ 水溶液を用いることにより試験体での屈折率を一 致させ, 流れ場全体の可視化を行えるようにした. またトレーサ粒子として, 有機蛍光物質 Rhodamine $\mathrm{B},\left(\mathrm{C}_{28} \mathrm{H}_{31} \mathrm{ClN}_{2} \mathrm{O}_{3}\right)$ を塗布した直径 10 $\mu \mathrm{m}$ の真球状微粒子ポリマーを混入した.

トレーサを混入した NaI 水溶液にレーザシートを照 射すると，気泡は YaG レーザの波長 $532 \mathrm{~nm}$ の光を反 射し，トレーサ粒子は $580 \mathrm{~nm}$ をピークとする波長で発 光する，そこで，液相速度を得るためには気泡からの 散乱光をカットする長波長透過フィルタ, また気相速 度を得るためにはトレーサ粒子からの蛍光をカットす る短波長透過フィルタを使用して，それぞれ画像を取 得した.

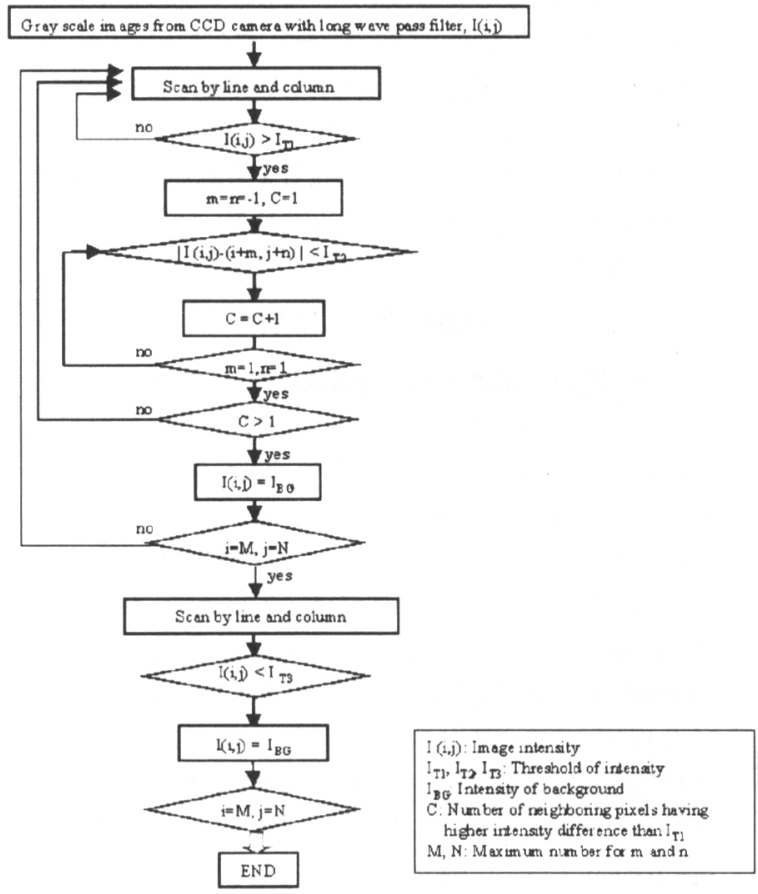

Fig. 4 Flow chart of the process to separate gas-liquid images
得られたそれぞれの画像から，粒子径と気泡径の 大きさの違いにより判別して液相については気泡を, 気相についてはトレーサ粒子を除去する処理を行って, 気液の速度分布を得た。

$2 \cdot 3$ 画像処理方法上述の光学的な手法では, 気泡とトレーサ粒子を完全には分離しきれないため, 画像解析の誤差を大きくする可能性がある. そこで, 気液の画像を光学的に分離した後, さらに画像処理を によって分離した. 得られた画像の解析から, トレー サ粒子からの発光は 1 ピクセル（約 $0.095 \mathrm{~mm}$ ）以下で あることに着目し，粒子の大きさによってトレーサ粒 子か気泡かを判別する.

液相流速を得るために気泡を除去する処理の流れ を図 4 に示寸. 長波長透過フィルタを通して CCD カ メラで撮影した画像では，トレーサ粒子はある輝度以 上であり粒子は小さい，したがって，この画像から輝 度が連続して大きい画像を気泡とみなして消去する。 まず，画像を縦横に 1 ピクセルづつ調べ，着目したピ クセルの輝度 $\mathrm{I}(\mathrm{i}, \mathrm{j})$ がある輝度のしきい值 $\mathrm{I}_{\mathrm{T}}$ 以上であ る場合，隣接する 8 ピクセルの差を計算し，その差が $\mathrm{I}_{\mathrm{T} 2}$ 以下であるものが 2 以上で連続している場合に, それを気泡と見なしバックグランドの輝度 $\mathrm{I}_{\mathrm{BG}}$ に変更 する. しかしながら，この処理だけでは計測面以外の レーザの反射によって写る輝度の小さい気泡や, 気泡 の輪郭が残る. そこで次に, ある輝度 $\mathrm{I}_{\mathrm{T}}$ 以上のトレー サ粒子のみを残寸ために, 輝度がしきい值 $\mathrm{I}_{\mathrm{T}}$ 以下であ るものを消去する.

一方，気泡流速を得るためには，短波長透過フィ ルタを通して得られた画像から小さいトレーサ粒子を 除去する必要がある．トレーサ粒子の大きさが 1 ピク セル以下であることを利用して判別を行う. 画像を液 相の場合と同様に 1 ピクセルづつ輝度を調心，着目す るセル輝度 $I(i, j)$ とその両隣のピクセルの輝度 $I(i-1, j)$ と $\mathrm{I}(\mathrm{i}+\mathrm{l}, \mathrm{j})$ との差をとり，どちらもある輝度 $\mathrm{I}_{\mathrm{T} 4}$ 以上で ある場合は，トレーサ粒子であるとしてバックグラン ドの輝度 $\mathrm{I}_{\mathrm{BG}}$ に変更する.

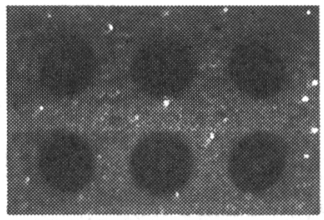

a) Original image with a filter

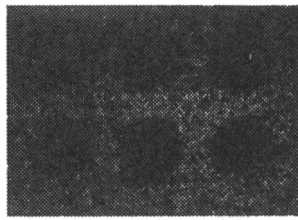

b) Separated image for liquid phase
Fig. 5 The original image of two phase flow and its separation results. 
Table 2 Factors of uncertainty in PIV measurement.

\begin{tabular}{|c|c|c|c|c|c|}
\hline Parameter & Error category & Elemental error source & $\begin{array}{l}\text { Absolute bias } \\
\left.\text { limit ( } B_{j}\right)\end{array}$ & $\begin{array}{l}\text { Absolute precision } \\
\text { index }\left(\mathbf{S}_{\mathrm{i}}\right)\end{array}$ & $\begin{array}{l}\text { Absolute sensitivity } \\
\text { coefficient }\left(\theta_{i}\right)\end{array}$ \\
\hline \multirow[t]{6}{*}{$\alpha$} & \multirow[t]{6}{*}{ Calibration } & Image length & 0.7 pix & - & $0.008 \mathrm{~mm} / \mathrm{pix}^{2}$ \\
\hline & & Physical location & $0.0122 \mathrm{~mm}$ & - & 0.089 \\
\hline & & Lens distortion & 0.056 pix & - & $0.008 \mathrm{~mm} / \mathrm{pix}^{2}$ \\
\hline & & CCD chip distortion & 0.006 pix & - & $0.008 \mathrm{~mm} / \mathrm{pix}^{2}$ \\
\hline & & Inorthogonality of optical axes & $0.035 \mathrm{rad}$ & - & $0.006 \mathrm{~mm} / \mathrm{pix}$ \\
\hline & & Location of laser sheet illumination & $0.5 \mathrm{~mm}$ & - & $0.04 \mathrm{l} / \mathrm{pix}$ \\
\hline \multirow[t]{6}{*}{$\Delta X$} & \multirow{3}{*}{$\begin{array}{l}\text { Data } \\
\text { acquisition }\end{array}$} & Temporal/spatial fluctuation of laser intensity & $0.028 \mathrm{~mm}$ & - & $11.2 \mathrm{pix} / \mathrm{mm}$ \\
\hline & & CCD chip distortion & 0.006 pix & - & 1 \\
\hline & & Inorthogonality of optical axes & $0.035 \mathrm{rad}$ & - & 0.174 pix \\
\hline & \multirow{3}{*}{$\begin{array}{l}\text { Data } \\
\text { processing }\end{array}$} & $\begin{array}{l}\text { Sub-pixel accuracy (detection of particles } \\
\text { displacement) }\end{array}$ & 0.017 pix & 0.033 pix & 1 \\
\hline & & Smoothing by reference matrix & 0.073 pix & - & 1 \\
\hline & & Error vector & - & $0.727 \mathrm{~mm} / \mathrm{s}$ & $0.037 \mathrm{~mm} \cdot \mathrm{pix}$ \\
\hline \multirow[t]{2}{*}{$\Delta t$} & \multirow{2}{*}{$\begin{array}{l}\text { Data } \\
\text { acquisition }\end{array}$} & Trigger pulse & $2 \mathrm{E}-9 \mathrm{~s}$ & 2E-9 s & 1 \\
\hline & & Timing of laser illumination & $5 \mathrm{E}-10 \mathrm{~s}$ & SE-10s & 1 \\
\hline \multirow[t]{3}{*}{$\Delta \mathrm{u}$} & \multirow{3}{*}{$\begin{array}{l}\text { Measurement } \\
\text { principle }\end{array}$} & Fluid traceability (acceleration response) & $3.734 \mathrm{E}-10 \mathrm{~mm} / \mathrm{s}$ & - & 1 \\
\hline & & Fluid traceability (gravitational subsidence) & $0.008 \mathrm{~mm} / \mathrm{s}$ & - & 1 \\
\hline & & Particles projection & $0.196 \mathrm{~mm} / \mathrm{s}$ & - & 1 \\
\hline
\end{tabular}

上述の処理によって得られた液相の画像の例を図 5 に示す. 長波長透過フィルタを通して得られた画像に は，粒子が大きく輝度の明るい気泡，粒子が大きく暗 い気泡，粒子が小さく明るいトレーサ粒子の 3 種類が 含まれている．画像処理によって，明るい気泡と暗い 気泡が除去され，トレーサ粒子のみの画像が得られて いることがわかる。

$2 \cdot 4$ 不㤸さ評洒 PIV 計測の際は, a) 校正に伴 う誤差, b) データ収集に伴う誤差, c) データ処理に 伴う誤差，d) 計測原理に伴う誤差が生じる ${ }^{[11]}$ (詳しく は表 2 に示す) . 誤差の伝播は偏り誤差と偶然誤差に 分けられ, それぞれ正確度 $B$ (Bias limit) と精密度 $S$ (Precision index)を指標として表される. 正確度は偏り 誤差の上限を示すものである. 不確かさ解析において は, 誤差要因からこの正確度と精密度を算出し, これ らの二乗和をとることで不確かさを評価する. 複数の 偏り誤差がある場合の正確度は, それぞれの正確度を 求めた上で, 誤差の伝播メカニズムにしたがって次式 で評価する ${ }^{[12]}$

$$
\begin{aligned}
& B=\sum_{i=1}^{N}\left(B_{i} \theta_{i}\right)^{2} \\
& S=\sum_{i=1}^{N}\left(S_{i} \theta_{i}\right)^{2}
\end{aligned}
$$

ここで, $B_{i}$ は要因 $i$ の単位をもった正確度, $S_{i}$ は要因 $i$ の単位をもった精密度, $\theta_{i}$ はその感度係数である.

2 時刻の画像の時間間隔を $\Delta[\mathrm{s}]$, 粒子の画像上での 変位量を $\Delta Y$ [pixel], 撮影された画像の変換係数を $\alpha[\mathrm{m} / \mathrm{pixel}]$, 物理空間での流体速度を $u[\mathrm{~m} / \mathrm{s}]$ とすると， 次の関係式が成立する.

$$
u=\alpha \frac{\Delta X}{\Delta t}+\varepsilon
$$

ここで， $\varepsilon[\mathrm{m} / \mathrm{s}]$ はPIV 計測に伴う誤差である. $u$ の 不確かさを評価する場合， $\Delta t ， \Delta X ， \alpha$ に起因する誤 差および計測原理に起因する誤差伝播を計算する必要 がある. 感度係数 $\theta_{i}$ は式(3)をそれぞれのパラメータで 微分することにより得られるが, 各要因の感度係数を 求め, 式(1),(2)によって各誤差を総括することにより, 最終的に速度の精密度, 正確度および不確かさが得ら れる. 誤差要因となるレンズひずみ，光軸非直交性， 照明の不均一，トレーサの追従性等を考慮して正確度 と精密度をそれぞれ算出し総括した結果，本計測にお ける速度の誤差は $8.6 \%$ となった。

\section{3. 試秸果およひ考察}

\section{$3 \cdot 1$ 可視化試资体およひ試食装置 発光間隔 5}

ms のストロボを用いて正方配列の流動様式を観察し た結果を図 6 に示す. 正方配列では, 気相流束 $j_{G}$ $=1.85 \times 10^{-3} \mathrm{~m} / \mathrm{s}$, 液相流束 $j_{L}=3.7 \times 10^{-2} \mathrm{~m} / \mathrm{s}$ (図 6a) のとき, 気泡は管の間の主流領域を上昇し，管の後流域に気泡 は分布しない. このときの気泡径は 2-3mm で, 気泡の 挙動は浮力の効果が支配的である. 液相流束が $j_{L}$ $=1.0 \times 10^{-1} \mathrm{~m} / \mathrm{s}$ (図 6b)になると, 気泡径が $1-2 \mathrm{~mm}$ と小さ くなると同時に, 気泡の挙動は乱れの増加にともなっ て横方向に大きくなり，上段の管に頻繁に衝突しクロ スフローとなる. さらに液相流束が大きく $j_{L}=3.0 \times 10^{-1}$ $\mathrm{m} / \mathrm{s}$ (図 6c) では, 気泡はさらに小径化して管の後流に 引き込まれ渦領域に気泡がトラップされて主流領域よ りも管上部で気泡が多く分布する. 


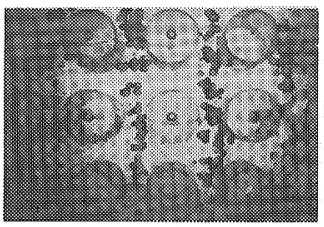

(a)

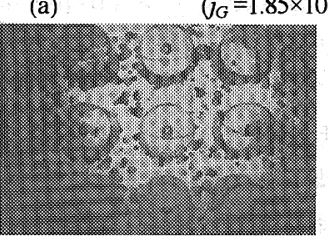

$\left(j_{G}=1.85 \times 10^{-3}, j_{L}=1.0 \times 10^{-1}\right)$

(b)

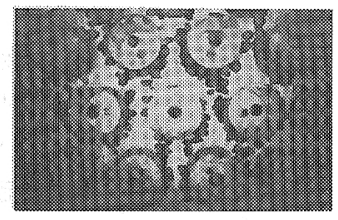

(d)
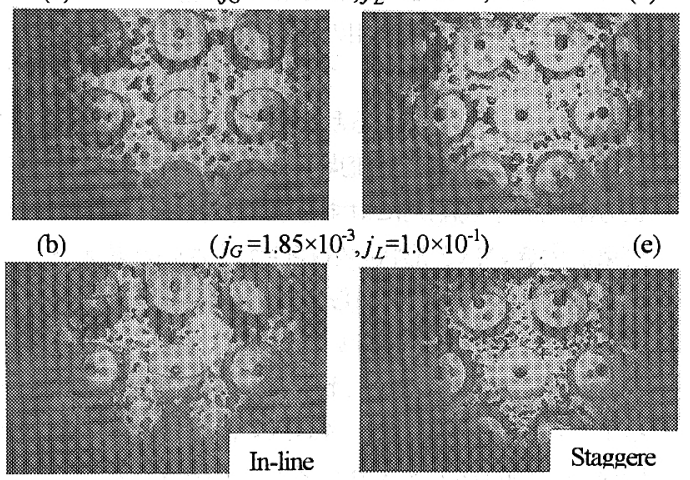

(c)

$$
\left(j_{G}=1.85 \times 10^{-3}, j_{L}=3.0 \times 10^{-1}\right)
$$

Fig. 6 Flow pattern visualized by $5 \mathrm{~ms}$ strobe light.

一方, 千鳥配列では, 気相流束 $j_{G}=1.85 \times 10^{-3} \mathrm{~m} / \mathrm{s}$, 液 相流束 $j_{L}=3.7 \times 10^{-2} \mathrm{~m} / \mathrm{s}$ (図 6d) のときは, 気泡は管壁に 沿って上昇し側面で管壁から離脱して上段の管の下面 に付着するという挙動によって，正方配列と同様に液 単相領域が形成される. 液相流束が $j_{L}=1.0 \times 10^{-1} \mathrm{~m} / \mathrm{s}$ (図 6e)になると，気泡は管壁から離脱した後，後上部に 引き込まれて単相領域は小さくなる. さらに液相流

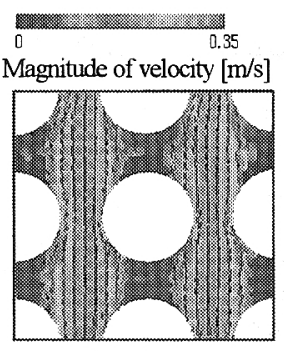

Gas phase a) $j_{G}=3.70 \times 10^{-3}, j_{L}=1.0 \times 10^{-1}$

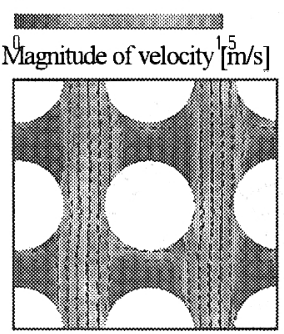

Gas phase
Unit of $j_{G}, i_{J}:\lceil\mathrm{m} / \mathrm{s}\rceil$

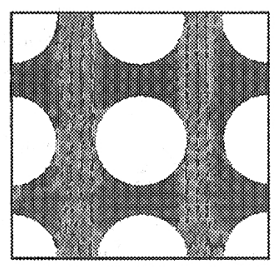

Liquid phase

b) $j_{G}=3.70 \times 10^{-3}, j_{L}=1.0 \times 10^{-1}$

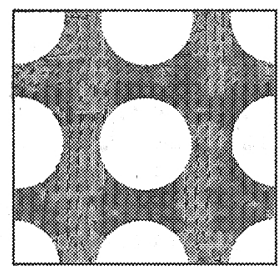

Liquid phase c) $j_{G}=3.70 \times 10^{-3}, j_{L}=3.0 \times 10^{-1}$

d) $j_{G}=3.70 \times 10^{-3}, j_{L}=3.0 \times 10^{-1}$

Fig. 7 Velocity vector fields of each phase in the inline array obtained by PIV.
束が $j_{L}=3.0 \times 10^{-1} \mathrm{~m} / \mathrm{s}$ (困 6f) と大きくなると，気泡は管 の直上部にも流入し気泡分布が全預域に均一化する. 正方配列のように管上部で気泡が循環することはなく， 流れの分岐と合流によって，正方配列に比べてより均 質に近い分布となっている.

$3 \cdot 2$ 速度分布 PIV 計測によって得られた正方 配列の気液の速度ベクトルを図 7 に, 千鳥配列の速度 ベクトルを図 8 に示す. 気相速度は前述の流動様式と ほぼ一致する結果が得られた。 寸なわち，正方配列の 場合は, 液相流束 $j_{L}<1.0 \times 10^{-1} \mathrm{~m} / \mathrm{s}$ のとき, 気泡は管の 間の主流領域に主に分布するが，液相流束 $j_{L}>$ $3.0 \times 10^{-1} \mathrm{~m} / \mathrm{s}$ になると管の後流領域に引き込まれる.こ のとき，気泡は管を横切るクロスフローとなるが，管 の一段毎に流れの向きが変り，主流にも蛇行がみられ る. また千鳥配列では，液相流束 $j_{L}<1.0 \times 10^{-1} \mathrm{~m} / \mathrm{s} \sigma$ と き，気泡は常に管壁に沿って上昇し，管の後流には単 相領域が形成されているが, 液相流束 $j_{L}>3.0 \times 10^{-1} \mathrm{~m} / \mathrm{s}$ では管の後流に気泡が引き込まれ、単相領域が消失し ている.

図 9 に正方配列の気液の $\mathrm{y}$ 方向速度成分を示す。 横軸は試験体の中心を 0 とし, 管径で無次元化して示 した. 気相流束 $j_{G}=3.70 \times 10^{-3} \mathrm{~m} / \mathrm{s}$, 液相流束 $j_{L}=3.7 \times 10^{-2}$ $\mathrm{m} / \mathrm{s}$ のとき(Fig.9(a))，管上部の領域は極めて流速の小 さい液相で満たされ，気泡の速度は○である. 主流領 域での気液速度の差は大きく, 気液の速度比は 2.0 以 上である. 液相流束 $j_{L}=1.0 \times 10^{-1} \mathrm{~m} / \mathrm{s}$ では, 管上部で気

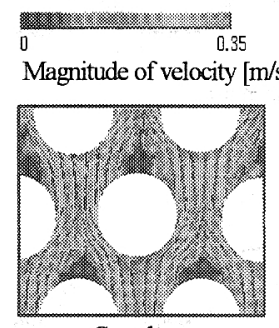

Gas phase

a) $j_{G}=3.70 \times 10^{-3}, j_{L}=1.0 \times 10^{-1}$

0 Magnitude of velocity $[\mathrm{m} / \mathrm{s}]$

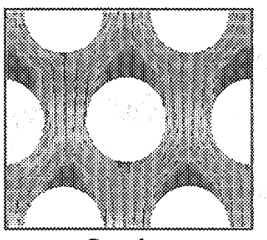

Gas phase

c) $j_{G}=3.70 \times 10^{-3}, j_{L}=3.0 \times 10^{-1}$
Unit of $i_{r}, i_{s}:\lceil\mathrm{m} / \mathrm{s}\rceil$

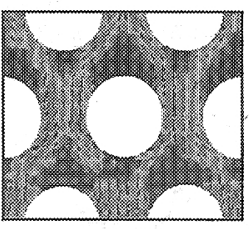

Liquid phase

b) $j_{G}=3.70 \times 10^{-3}, j_{L}=1.0 \times 10^{-1}$

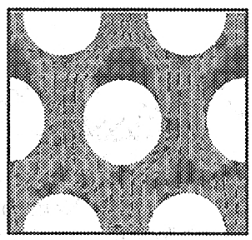

Liquid phase

d) $j_{G}=3.70 \times 10^{-3}, j_{L}=3.0 \times 10^{-1}$
Fig. 8 Velocity vector fields of each phase in the staggered array obtained by PIV. 
泡速度は負から正一と変化しており循環していること る. 液相流束 $j_{L}=3.0 \times 10^{-1} \mathrm{~m} / \mathrm{s}$ で, 管上部の循環領域は 大きくなり,この影響で主流の発達が抑制される. 主 流域の速度比は循環領域に比べてなお大きく，このた めボイドの分布が主流よりも管の上部で大きくなると 考えられる.

同様に, 千鳥配列の $\mathrm{y}$ 方向速度成分を図 10 に示す. 気相流束 $j_{G}=3.70 \times 10^{-3} \mathrm{~m} / \mathrm{s}$ においては, 二相それぞれの 速度分布は正方配列に比べて平坦で，管上部の単相領 域は正方配列より小さい. 液相流束 $j_{L}=1.0 \times 10^{-1} \mathrm{~m} / \mathrm{s}$ で は，管上部の後流が発達しこの領域での二相の速度差 は小さいが，流体の分岐領域ではなお大きい. 液相流 束 $j_{L}=3.0 \times 10^{-1} \mathrm{~m} / \mathrm{s}$ では, 後流域で気泡の逆流がみられ、 二相の速度差はより小さく，流路断面を通じてほぼ一 様となっている.

$3 \cdot 3$ 乱流强度 図 11 は, 液相流束 $j_{L}=1.0 \times 10^{-1}$ $\mathrm{m} / \mathrm{s}, 3.0 \times 10^{-1} \mathrm{~m} / \mathrm{s}$ の場合に, 二相流の乱流強度を単相 の結果 ${ }^{[9]}$ と比較したものである. データは流動状態が 安定する 5 段目と 6 段目の管の中間断面でのものであ る. 液相流束の増加に伴って乱流強度は増大しており, 前述のような気泡分布の変化に影響を与えていると考
えられる. 単相流に比べて二相流では乱流強度が増大 するが, 正方配列では後流域に比へて主流領域で乱流 強度が大きくなるのに対し，千鳥配列では断面全体に わたって大きくなっていることがわかる. 単相から二 相に変化した場合の乱流強度の増加割合は, 正方配列 の方が大きい. たとえば, 液相流束 $j_{L}=1.0 \times 10^{-1} \mathrm{~m} / \mathrm{s}$ のとき, 正方配列の単相の場合の平均乱流強度は千鳥 配列の 0.57 倍であるが, 二相流の場合は 0.87 倍で, 二 相流の場合の形状による乱流強度の差は, 単相に比べ て小さい. また, 液相流束 $j_{L}=3.0 \times 10^{-1} \mathrm{~m} / \mathrm{s}$ のときの 正方配列の千鳥配列に対する乱流強度の比は 0.95 で, 流束が大きいほど形状の依存性が小さいと言える.

乱流強度の大きさから，対流熱伝達率は正方配列 に比べて千鳥配列で大きいと推定される. しかしなが ら, 沸騰二相流においては, Chen 型の相関式で示され るように，熱伝達メカニズムは対流熱伝達と核沸滕熱 伝達の二つの熱伝達メカニズムに支配される. 二つの メカニズムの相対的な大きさについては, Chan and Shoukri (1987)が, 低熱流束の場合は二相対流熱伝達の 効果が支配的で, 高熱流束の場合は核沸腾熱伝達が支 配的であると報告している ${ }^{[13]}$. 核沸騰は対流によって

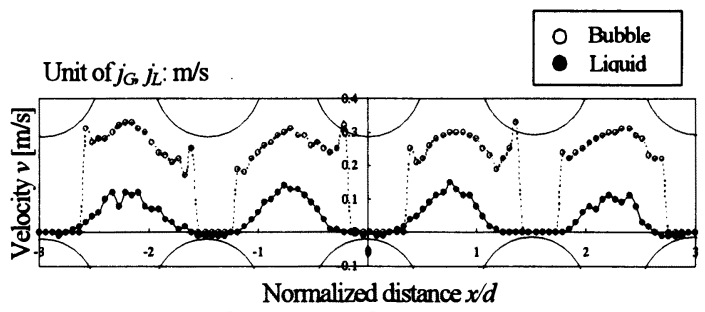

a) $j_{G}=3.70 \times 10^{-3}, j_{L}=3.7 \times 10^{-2}$

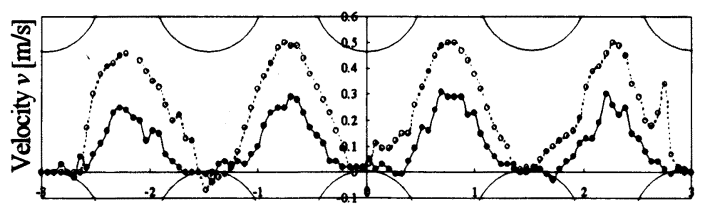

b) $j_{G}=3.70 \times 10^{-3}, j_{L}=1.0 \times 10^{-1}$

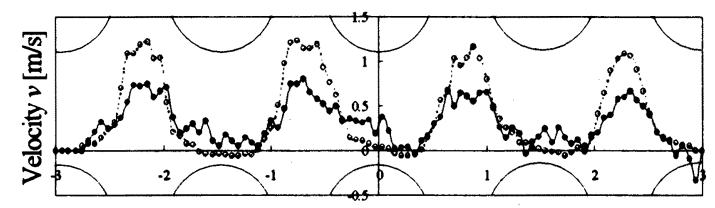

c) $j_{G}=3.70 \times 10^{-3}, \begin{aligned} & \text { Normalized dist } \\ & j_{L}=3.0 \times 10^{-1}\end{aligned}$

Fig. 9 Velocity distributions of liquid and gas phases behind 1 st row of tubes in in-line array.

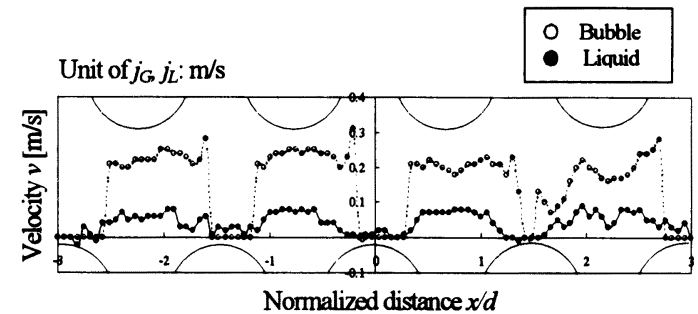

a) $j_{G}=3.70 \times 10^{-3}, j_{L}=3.7 \times 10^{-2}$

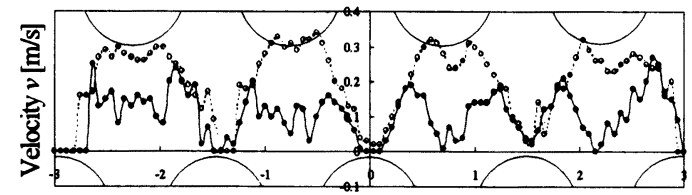

Normalized distance $x / d$

b) $j_{G}=3.70 \times 10^{-3}, j_{L}=1.0 \times 10^{-1}$

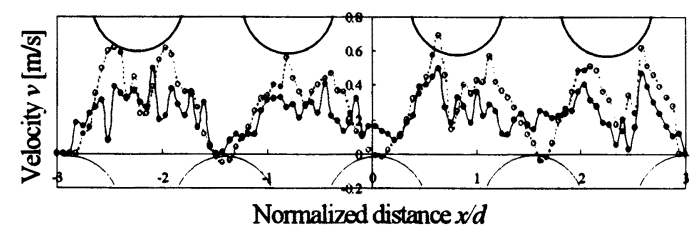

c) $j_{G}=3.70 \times 10^{-3}, j_{L}=3.0 \times 10^{-1}$

Fig.10 Velocity distributions of liquid and gas phases behind $1 \mathrm{st}$ row of tubes in staggered array. 


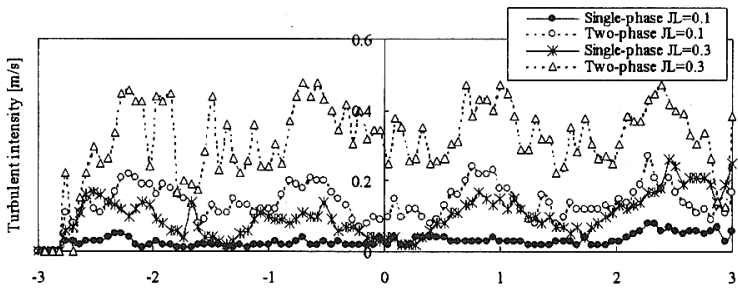

(a) In-line array

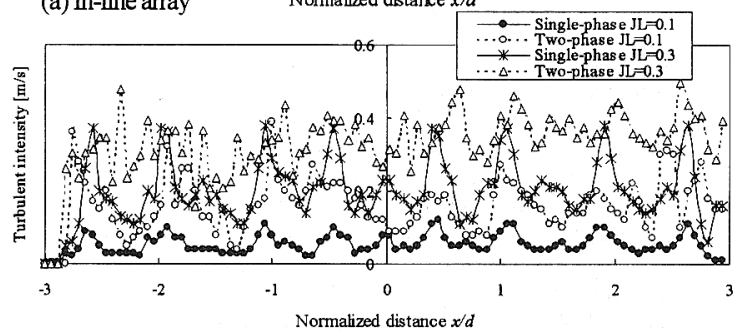

(b) Staggered array

Fig.11 Turbulence intensity

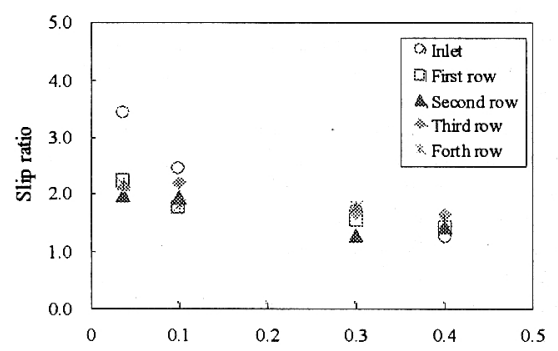

(a) In-line array

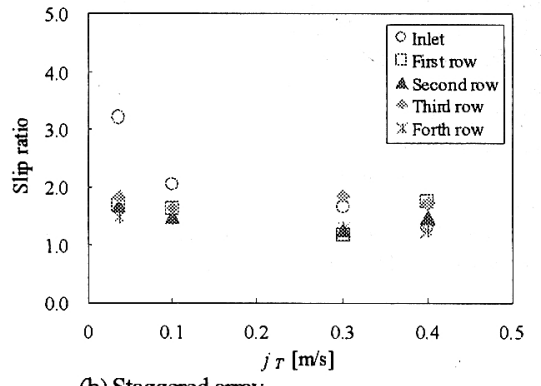

(b) Staggened array

Fig.12 Slip ratio obtained at $j_{G}=1.85 \times 10^{-3} \mathrm{~m} / \mathrm{s}$.

抑制されるため，熱伝達特性の評価については别途温 度分布の計測が必要である。

さらに，前述のような気泡の分布や速度分布の相 違は，局所的な熱伝澾率に大きく影響すると推定され る.

3-4 スリップ比 PVによって得られた気液速度 のスリップ比, $S\left(=u_{G} / u_{L}\right)$ を, 1 段目から 4 段目までの 断面平均を計算し, 全体積流束 $j_{T}\left(=j_{G}+j_{L}\right)$ に対する 依存性について表したものが，図12 である。全体積
流束が大きくなるにつれて，スリップ比は小さくなり 均質流に近づく，これは，前述のように気泡の小径化 と液相の乱れの増大が要因と考えられる。また，スリ ップ比は管群の入口における值に対して管群の中で低 下しており，特に全体積流束 $j_{T}$ が小さいほどこの傾向 が大きい. 全体積流束 $j_{T}=3.0 \times 10^{-1} \mathrm{~m} / \mathrm{s}$ 以上では，入口 と管群内でのスリップ比の差は非常に小さくなるが, これは前述のように，全体積流束 $j_{T}$ が小さいほど管群 による乱れ増大の効果が大きいためと考えられる.

管群配列による相違については, 全体積流束 $j_{T}$ が小 さいときに正方配列の方がスリップ比は大きい傾向が ある. 正方配列では流路の特徴により主流を上昇する 気泡の割合が多い，一方，千鳥配列では，単相での計 測結果から影も明らかなように，交互に配置された管 によって分岐と合流が繰り返される結果、流れ場全体 にわたって液相の乱れが促進され，スリップ比が小さ くなると推定される. しかしながら，全体積流束 $j_{T}$ $=3.0 \times 10^{-1} \mathrm{~m} / \mathrm{s}$ 以上では配列によるスリップ比の差は小 さく，これは前述のように配列による乱流強度の差が 小さくなるためと考えられる.

3・5 ポイド率ＰIVによって得られた画像デー 夕平均ボイド率を算出してクオリティに対して整理し, 従来のボイド率相関式と比較したものを図 13 に示す. ここで, Zuber-Findlay のドリフトフラックスモデル式 において使用される係数には，発達した矩形流路にお ける気泡流の式を用いた。 実験で得られたボイド率は, クオリティが小さいときは均質流モデルに近いが，ク オリティの増加とともに均質流モデルより小さくなっ ている．均質流モデルに比べて，Thom やZivi の相関 式はこの範囲では均質流モデルに比べてかなりボイド 率を小さく評価するため, 低クオリティでは実験值を

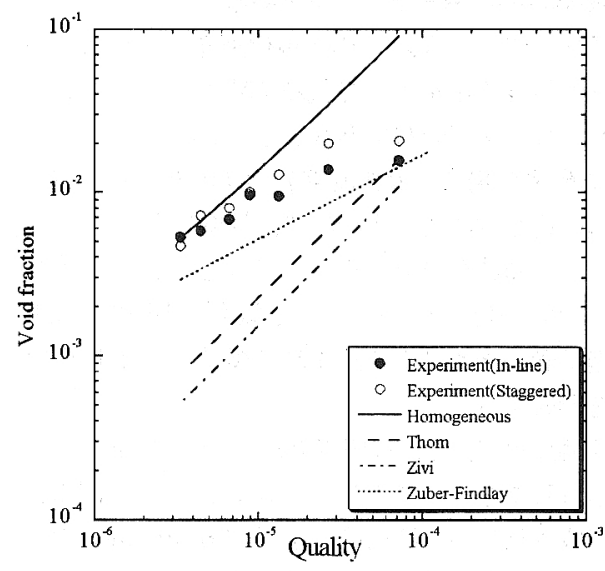

Fig.13 Variation of the void fraction with quality. 


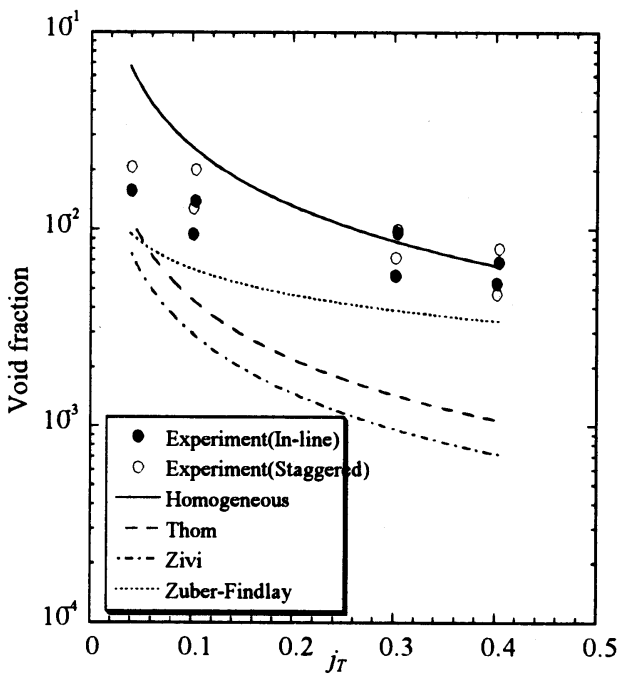

Fig.14 Variation of the void fraction with total superficial flux.

大きく過小評価するが，クオリティが $10^{-4}$ ではよく一 致している. 一方, ドリフトフラックスモデルの式は 全体的に実験值を過小評価するが，クオリティに対す るボイド率の傾向を比較的よく表していると言える.

同データを全体積流束 $j_{T}$ について整理したものを 図 14 に示寸. 全体積流束 $j_{T}$ が大きいほどボイド率は 均質流に近づくことが明らかである.以上のことから， 管群を上昇する気泡流では，全体積流束が $j_{T}=0.3 \mathrm{~m} / \mathrm{s}$ 以上ではほぼ均質流と見なせるが, $0.1 \mathrm{~m} / \mathrm{s}$ 以下では均 質流の仮定は成立しなくなると言える.

\section{4. 結言}

PIV を管群を上昇する気泡流に適用し，得られた詳 細流動構造の特徵を下記にまとめる.

(1)管群を上昇する気泡流の可視化画像を, 光学的手法 と画像処理手法を用いて気液分離することにより, それぞれの速度分布を得ることができた。

(2)正方配列の場合, 液相流束 $j_{L}<1.0 \times 10^{-1} \mathrm{~m} / \mathrm{s}$ では, 気泡の運動は浮力が支配的で，管壁によって形成さ れる主流領域を浮上するが, 液相流束 $j_{L}>3.0 \times 10^{-1}$ $\mathrm{m} / \mathrm{s}$ では, 液相の乱れの增加と気泡の小径化により, 気泡は管の後流に引き込まれて循環し, 高ボイド領 域を形成する。

(3)千鳥配列の場合は, 液相流束 $j_{L}<1.0 \times 10^{-1} \mathrm{~m} / \mathrm{s}$ では, 気泡は管壁を沿って上昇し，管上部には液単相領域 が形成されるが，液相流束 $j_{L}>3.0 \times 10^{-1} \mathrm{~m} / \mathrm{s}$ では, 気泡は管の後流域へ引き込まれて液単相領域が消失
する. しかしながら，気泡は正方配列のように管上 部で循環することなく全領域にほぼ均一に分布する. (4) 低流束では均質流の仮定は成り立たないが、全体 積流束 $j_{T}>3.0 \times 10^{-1} \mathrm{~m} / \mathrm{s}$ ではほぼ均質流とみなせる. このとき，管群の配列による気泡の分布は異なるも の, 平均的なボイド率は両者でほぼ等しい.

\section{文城}

(1) I.D.R Grant, D. Chisholm, Two-phase Flow in the Shell-Side oh a Segmentally Baffled Shell-and-Tube Heat Exchanger. J. Heat Transfer 101 (1979) 38-42

(2) M. Kondo, K.I. Nakajima, Experimental Investigation of Air-Water Two-Phase Upflow across Horizontal Tube Bundles. Bulletin of the JSME, Vol.23, No.177 (1980) 385-393

(3) R. Urbrich, D. Mewes, Relation between Gas Void Fraction in Upward and Downward Flow. Multiphase Transport and Particulate Phenomena 2 (1994) 79-94

(4) G.R Noghrehkar et al., Investigation of Two-Phase Flow Regimes in Tube Bundles under Cross-Flow Conditions. Int. J. Multiphase Flow 25 (1999) 857-874

(5) D.S. Schrage et al., Two-Phase Pressure Drop in Vertical Cross-Flow Across a Horizontal Tube Bundle. AIChEJ 34 (1988) $107-115$

(6) R. Dowlati et al., Pitch-to-Diameter Effect on Two-Phase Flow Across an In-Line Tube Bundle. AIChEJ Vol.36 (1990) 765-772

(7) R. Dowlati et al., Hydrodynamics of Two-Phase Flow across Horizontal In-Line and Staggered Rod Bundles. Trans. ASME J. Fluids Engineering Vol.114 No.3, 450-456.

(8) R Dowlati et al., Void Fraction Prediction in Two-Phase Flow across a Tube Bundle. Trans. AIChEJ 38(1992)619-622

(9) Iwaki C. et al., PIV Measurement of the Vertical Cross-Flow Structure over Tube Bundle. Experiments in Fluids 37(2004) 350-363

(10) Matsui G et al., Flow Characteristics in Channel with Local Blockage Packed with Spheres. Proc. of Experimental Heat Transfer, Fluid Mechanics and Thermodynamics ExHFT-5(2001) 1675-1682

(11) Particle Image Velocimetry Handbook (In Japanese). Japan Visualization Society of Japan (2002)

(12) ASME Performance Test Codes, Supplement on Instruments and Apparatus, Part1-Measurement Uncertainty. ANSI/ASME PTC 19.1(1985)

(13) A.M.C. Chan, M. Shoukri, Boiling Characteristic of Small Multitube Bundles. Transactions of the ASME 